\title{
Program Pengembangan Layanan Perpustakaan di Sekolah Menengah Atas: Studi Kasus di SMAN 2 Bantul
}

\author{
Meilina Bustari \\ Universitas Negeri Yogyakarta, Yogyakarta, DIY, Indonesia
}

Corresponding author: Meilina Bustari (e-mail: meilinabustari@uny.ac.id)

\begin{abstract}
Abstrak: Penelitian ini bertujuan untuk mendeskripsikan program pengembangan layanan perpustakaan sekolah di Sekolah Menengah Atas Negeri 2 Bantul. Metode pada penelitian ini menggunakan metode kualitatif. Sumber data dalam penelitian ini adalah kepala perpustakaan, tenaga pengelola perpustakaan sekolah, dan relawan pustakawan muda. Metode pengumpulan data menggunakan teknik wawancara, observasi, dan dokumentasi. Uji validitas data menggunakan triangulasi sumber dan metode. Teknik yang digunakan untuk menganalisis data adalah analisis data Miles dan Huberman. Hasil penelitian ini menunjukkan bahwa: (1) bentuk program pengembangan layanan perpustakaan di Sekolah Menengah Atas Negeri 2 Bantul meliputi kegiatan layanan untuk difabel, narapidana, dan kegiatan di panti jompo; (2) proses pelaksanaan kegiatan layanan perpustakaan terdiri a tas: (a) layanan untuk difabel dengan mengundang siswa difabel dari luar sekolah untuk mengikuti kegiatan story telling; (b) layanan bagi narapidana dilakukan dengan mengganti koleksi setiap dua bulan sekali; dan (c) layanan di panti jompo dilakukan dengan mengganti koleksi dalam jangka waktu dua bulan sekali dan memberi pendampingan bagi manula dalam memanfaatkan koleksi.
\end{abstract}

Kata Kunci: program pengembangan, layanan perpustakaan, perpustakaan sekolah

\section{Development Program of Library Services in Senior High School: Case Study in Public Senior High School 2 Bantul}

\begin{abstract}
This study aims to describe the school library service development program in public senior high school 2 Bantul. The study applied a qualitative research approach. The study involved the head of the school libraries, school library staff, and volunteers. The data collection methods applied were interviews, observations, and documentation. Triangulation techniques were used to achieve data validity. The data analysis followed the Miles and Huberman qualitative data analysis model. The results show that: (1) the library service development program includes providing special services for disabled students, inmates, and elderly at nursing home, (2) the library service activities include inviting students with disabilities from other schools to participate in the storytelling program; (b) providing reading collections for inmates that are renewed every two months; and (c) providing reading collections for the elderly people and an assistance to use the collections.
\end{abstract}

Keywords: development program, library service, school library 


\section{PENDAHULUAN}

Perpustakaan diartikan sebagai kumpulan buku atau bangunan fisik tempat buku dikumpulkan, disusun menurut sistem tertentu untuk kepentingan pemakai (Qalyubi, dkk., 2007). Di dalam Undang-Undang No. 43 tahun 2007 tentang perpustakaan, perpustakaan adalah institusi pengelola koleksi karya tulis, karya cetak,dan/atau karya rekam secara profesional dengan sistem yang baku guna memenuhi kebutuhan pendidikan, penelitian, pelestarian, informasi, dan rekreasi para pemustaka.

Peraturan Pemerintah No. 32 Tahun 2013 tentang Standar Nasional Pendidikan Pasal 42 ayat (2) mengatur bahwa setiap satuan pendidikan wajib memiliki pras arana yang salah satunya adalah ruang perpustakaan untuk menunjang proses pembelajaran yang teratur dan berkelanjutan. Selanjutnya Peraturan Pemerintah tersebut diperjelas dengan Peraturan Menteri Pendidikan Nasional (Permendiknas) No. 20 Tahun 2007 tentang Standar Sarana dan Prasarana untuk SD/MI, SMP/MTS, SMA/MA menyatakan bahwa sebuah SMA/MA sekurang-kurangnya memiliki prasarana sebagai berikut: ruang kelas, ruang perpustakaan, laboratorium biologi, laboratorium fisika, laboratorium kimia, laboratorium komputer, laboratorium bahasa, ruang pimpinan, ruang guru, ruang tata usaha, tempat beribadah, ruang konseling, ruang UKS, ruang organisasi kesiswaan, jamban, gudang, ruang sirkulasi, dan tempat bermain.

Berdasarkan Undang-Undang dan Peraturan Pemerintah tersebut, sekolah diharapkan memenuhi standar mutu dan peraturan yang berlaku untuk peningkatan mutu sekolah. Akan tetapi, pada kenyataannya, belum semua sekolah melaksanakan dan memenuhi peraturan dan standar mutu yang diberlakukan pemerintah. Harian Kompas yang terbit pada tanggal 8 Oktober 2012 menginformasikan bahwa masih banyak sekolah dari jenjang sekolah dasar (SD) sampai jenjang sekolah menengah atas (SMA), yaitu 76.478 sekolah, yang belum memiliki perpustakaan. Pelaksana Tugas Direktur Jenderal Pendidikan Dasar Kementerian Pendidikan dan Kebudayaan menjelaskan bahwa pada tahun 2012, pemerintah membangun 9.442 perpustakaan. Pada 2013, dibangun 1.500 perpustakaan lagi sehingga pada akhir tahun 2013 ditargetkan 75 persen SD sudah memiliki perpustakaan. Pada sekolah menengah pertama (SMP), 20.540 sekolah (63\% sekolah) sudah memiliki perpustakaan. Kekurangan perpustakaan yang cukup besar terjadi di sekolah menengah kejuruan (SMK). Dari 9.875 SMK, baru 4.362 sekolah atau kurang dari 50 persen yang memiliki perpustakaan. 5.513 sekolah siswanya tidak memiliki perpustakaan. Di tingkat SMA, 8.144 dari 11.535 sekolah yang telah memiliki perpustakaan. 3.391 sisanya belum memiliki perpustakaan. Salah satu penyebabnya yaitu perhatian dari pihak sekolah yang rendah dalam menanggapi Peraturan 
Pemerintah No. 19 Tahun 2005 tentang Standar Nasional Pendidikan dan Peraturan Menteri Pendidikan Nasional No 20 Tahun 2007 tentang Standar Sarana dan Prasara na.

Keberadaan perpustakaan sekolah menjadi hal yang penting sehingga perlu pengelolaan dan pengembangan yang optimal untuk menjaga dan meningkatkan peran dan fungsinya. Pengembangan perpustakaan merupakan upaya peningkatan semua komponenkomponen/unsur-unsur dalam penyelenggaraan perpustakaan, diantaranya yaitu komponen sumber day a manusia, koleksi bahan pustaka, sarana prasarana, keuangan, layanan, promosi, jaringan kerja sama, dan program terkait yang ada. Pengembangan perpustakaan ini didasarkan pada karakteristik, fungsi dan tujuan perpustakaan serta kebutuhan masyarakat penggunanya secara berkesinambungan. Perpustakaan perlu mengembangkan layanannya agar masyarakat sekitar ikut merasakan manfaat dan keberadaan perpustakaan sekolah. Selain itu, perpustakaan perlu mengadakan pengembangan layanan kepada pemustaka sebagai realisasi fungsi pengembangan literasi di lingkungan sekolah dan masyarakat.

Layanan pemustaka juga merupakan salah satu kriteria keberhasilan penyelenggaraan perpustakaan. Perpustakaan sekolah pada umumnya memberikan berbagai bentuk lay an an kepada pemustaka, diantaranya yaitu layanan sirkulasi (peminjaman dan pengembalian buku koleksi perpustakaan), referensi, minat baca, loker dan sebagainya. Berbagai bentuk lay an an perpustakaan tersebut juga dilaksanakan di perpustakaan sekolah menengah atas negeri (SMAN) 2 Bantul. Berdasarkan observasi awal peneliti di sekolah ini, perpustakaan sudah melaksanakan kegiatan layanan untuk warga sekolah dan masyarakat sekitar tetapi pelaksanaannya belum maksimal. Hal ini diperkuat dengan hasil observasi penulis yang menunjukkan bahwa tersedia koleksi yang lengkap dan tata ruang yang baik dan nyaman untuk pemustaka. Selain itu, layanan perpustakaan yang ada masih difokuskan untuk warga sekolah terutama guru dan siswa untuk mengoptimalkan aktivitas pembelajaran. Bentuk layanan perpustakaan yang telah diberikan antara lain layanan sirkulasi, lay anan referen si, layanan locker, layanan ruang baca, layanan audio visual, dan layanan minat baca. Namun, layanan bagi lingkungan eksternal perpustakaan khususnya masyarakat umum belum dilaksanakan secara maksimal.

Hasil wawancara dengan kepala perpustakaan menunjukkan bahwa sejauh ini kerja sama yang dijalin untuk masyarakat umum sekedar promosi dan menerima kunjungan dari instansi lain. Oleh karena itu, perpustakaan perlu mengupayakan program pengembangan layanan perpustakaan untuk masyarakat sekitar agar tercipta masyarakat yang literer. Penelitian ini bermaksud mendeskripsikan usaha program pengembangan layanan perpustakaan sekolah yang dilakukan Perpustakaan Prapanca SMAN 2 Bantul. Penelitian ini 
juga mendeskripsikan program pengembangan layanan eksternal perpustakaan sekolah yang telah dilakukan perpustakaan Prapanca SMAN 2 Bantul.

\subsection{Konsep perpustakaan sekolah}

Perpustakaan sekolah merupakan salah satu prasarana sekolah yang wajib dipenuhi dan diselenggarakan di sekolah. Dalam Peraturan Pemerintah Nomor 24 Tahun 2014 tentang perpustakaan sekolah dijelaskan bahwa perpustakaan sekolah/madrasah meru pakan bagian integral dari kegiatan pembelajaran yang berfungsi sebagai pusat sumber belajar untuk mendukung tercapainya kegiatan pendidikan dan pengajaran yang berkedudukan di sekolah/madrasah.

Perpustakaan sekolah merupakan sarana pendidikan untuk meningkatkan daya serap dan kemampuan penalaran peserta didik, memperluas pengetahuan guru dalam kegiatan mengajar sehingga koleksinya dapat disesuaikan dengan kurikulum. Perpustakaan sekolah diperuntukkan bagi semua warga sekolah, yaitu guru, peserta didik, dan karyawan. Perpustakaan tidak hanya menyimpan jenis buku saja tetapi juga berbagai karya media audiovisual seperti film, slide, kaset, dan bentuk mikro seperti mikrofilm dan mikrofis.

Grates (2013) mengatakan bahwa tujuan mendasar perpustakaan sekolah adalah menyediakan akses terhadap buku, akses tersebut merupakan faktor utama yang mendorong peningkatan nilai prestasi siswa di semua aspek keaksaraan. Akses terhadap buku-buku tidak hanya memupuk kegemaran membaca dan prestasi belajar namun juga untuk mengimbangi dampak kemiskinan. Oleh karena itu, sekolah hendaknya memandang penting keberadaan perpustakaan sekolah sebagai salah satu penunjang peningkatan kualitas pendidikan. Perpustakaan sekolah perlu diberdayakan melalui terobosan-terobosan agar dapat memaksimalkan pemanfaatannya.

\subsection{Layanan perpustakaan sekolah}

Kegiatan layanan di perpustakaan merupakan salah satu indikator yang penting dalam keberhasilan penyelenggaraan perpustakaan sekolah. Layanan perpustakaan merupakan kegiatan yang disiapkan untuk memberikan jasa terhadap produk yang dimiliki perpustakaan agar dapat dimanfaatkan masyarakat yang membutuhkan (Hartono, 2016). Hal ini sejalan dengan Inderiyeni (2017) bahwa aktivitas layanan perpustakaan merupakan penyediaan bahan pustaka secara tepat dan akurat dalam rangka memenuhi kebutuhan informasi bagi para pengguna perpustakaan. Oleh karena itu, secara garis besar layanan yang ada di 
perpustakaan sekolah harus sejalan dengan fungsi dan tujuan perpustakaan, yaitu me menuhi kebutuhan pemustaka melalui koleksi perpustakaan.

Menurut Sinaga (Prastowo, 2012: 245) perpustakaan sekolah adalah lembaga yang memberikan pelayanan terhadap seluruh pemakai perpustakaan sekolah. Pemakai perpustakaan sekolah tidak dibatasi hanya untuk guru dan murid, melainkan semua orang berhak mendayagunakannya. Berdasarkan pendapat tersebut, perpustakaan sekolah dapat dimanfaatkan oleh masyarakat sekitar sekolah walaupun dengan kriteria pemilihan masyarakat dan batas-batas tertentu yang telah disepakati bersama. Mansyur (2015) menjelaskan bahwa secara umum layanan perpustakaan dapat dibedakan menjadi dua bagian yaitu: (1) layanan teknis yang meliputi pengembangan koleksi, pengolahan, dan administrasi; dan (2) layanan pemustaka yang dapat berupa layanan sirkulasi peminjaman koleksi, layanan referensi, dan lain sebagainya.

Berkaitan dengan layanan pemustaka, kegiatan layanan yang ada di perpustakaan sekolah meliputi peminjaman buku-buku, layanan kebutuhan pelajaran dalam kelas, penyediaan sumber informasi bagi siswa dan guru, pendidikan kepada siswa agar dapat mencari informasi sendiri, dan pelatihan kepada siswa untuk mahir menggunakan bahan pustaka, seperti kamus, ensiklopedi, membaca peta, dan bola dunia (Harton o, 2016: 183).

\subsection{Program pengembangan layanan perpustakaan}

Perpustakaan sebagai pusat sumber belajar perlu diupayakan seoptimal dan semenarik mungkin melalui berbagai pemanfaatan sumber daya di sekolah. Salah satu upaya yang dapat dilakukan adalah pengembangan program layanan perpustakaan untuk masyarakat di sekitar lingkungan sekolah. Pengembangan dimaksudkan untuk memenuhi kebutuhan warga sekolah dan masyarakat di sekitar sekolah.

Program pengembangan layanan perpustakaan ini memiliki esensi yang sama dan menunjang implementasi pendidikan berbasis masyarakat. Model ini menekankan pada pelibatan siswa/peserta didik dalam aktivitas di dalam dan di luar kelas. Pelibatan masyarakat dalam hal perencanaan, pelaksanaan, maupun evaluasi efektivitas belajar da n pemanfaatan outcome (Fuad, 2014: 84). Pengembangan program perpustakaan hendaknya melibatkan peserta didik dan warga masyarakat dalam pengimplementasiannya. Pengembangan lay anan perpustakaan yang disesuaikan dengan kebutuhan masyarakat diharapkan dapat menumbuhkan dan meningkatkan minat baca masyarakat. Pengembangan tersebut berguna meningkatkan kualitas dan daya saing bangsa. Namun, dalam kenyataan di lapangan hal ini 
masih sulit dilaksanakan karena masih banyak kendala yang mengakibatkan rendahn ya minat baca masyarakat.

Salah satu kendala rendahnya minat baca masyarakat adalah pola pikirnya mengenai kebutuhan informasi. Menurut Steenerova dalam Hartono (2017) perlu membangun pola pikir dengan pendekatan budaya holistik dalam mengembangkan inovasi. Bukan hanya dilihat dari sudut rasionalitas tetapi juga dari sudut manusia melalui sistem budayanya dalam bentuk interaksi antara mereka maupun dengan lingkungannya. Oleh karena itu, perlu dibangun pola pikir masyarakat mengenai kebutuhan informasi dengan menyediakan literatur-literatur serta fasilitas pendukungnya yang memadai. Guna memenuhi kebutuhan tersebut, maka diperlukan program pengembangan layanan perpustakaan hingga ke masyarakat sekitarnya meliputi bentuk dan proses layanan perpustakaan.

\section{METODE PENELITIAN}

Penelitian ini menggunakan pendekatan kualitatif untuk mendeskripsikan tentang pengembangan layanan perpustakaan sekolah. Lokasi penelitian ini dilakukan di perpustakaan Prapanca SMAN 2 Bantul, yang dilaksanakan pada bulan Agustus 2018 sampai April 2019. Subjek penelitian adalah kepala sekolah, kepala perpustakaan, tenaga perpustakaan, dan siswa anggota relawan pustakawan muda di SMA N 2 Bantul. Mereka dipilih sebagai subyek penelitian karena mereka terlibat langsung dengan kebijakan dan penyelenggaraan perpustakaan Data penelitian bersifat kualitatif dengan teknik pengambilan data menggunakan wawancara, observasi dan dokumentasi.

Wawancara dilakukan dengan menggunakan sebuah instrumen panduan wawancara yang ditujukan pada kepala sekolah, kepala perpustakaan, tenaga perpustakaan, dan siswa anggota relawan pustakawan muda di perpustakaan SMA N 2 Bantul. Observasi dilakukan di perpustakaan terkait situasi sosial dan kondisi perpustakaan, fasilitas-fasilitas pendukung penyelenggaraan perpustakaan. Studi dokumen dilakukan terhadap dokumen profil perpustakaan dan pedoman penilaian akreditasi perpustakaan. Data yang telah dikumpulkan kemudian dianalisis dengan teknik analisis interaktif yang mengacu pada pendapat Miles dan Huberman yang terdiri dari langkah-langkah pengumpulan data, reduksi data, penyajian data dan penarikan kesimpulan. Uji keabsahan data menggunakan triangulasi sumber dan metode, dilakukan pada saat pengumpulan data agar data yang diperoleh valid dan reliabel.

\section{HASIL}

\subsection{Bentuk program pengembangan layanan perpustakaan}


Data hasil penelitian menunjukkan bahwa program pengembangan layanan perpustakaan yang dilaksanakan di perpustakaan Prapanca SMAN 2 Bantul terdiri atas beberapa program. Program tersebut meliputi layanan untuk difabel, narapidana, dan jompo. Berbagai lay anan tersebut diuraikan lebih detail sebagai berikut.

\subsubsection{Layanan perpustakaan untuk siswa difabel}

Pengembangan program layanan perpustakaan ini mendukung implementasi sekolah inklusi di SMAN 2 Bantul. Siswa difabel berhak memanfaatkan bahan pustaka di perpustakaan sebagai sumber belajar. Oleh karena itu, perpustakaan Prapancan SMAN 2 Bantul menyediakan koleksi bagi siswa difabel. Koleksinya berupa buku braille, alat khusus untuk penyandang tuna rungu, dan media audio visual.

Hal tersebut diperkuat dengan hasil wawancara dengan kepala perpustakaan pada tanggal 10 Agustus 2018 yang menyatakan bahwa

"koleksi bahan pustaka di SMA ini juga mengakomodasi para siswa difabel mbak, ada beberapa macam koleksi yang disediakan".

Demikian pula yang diungkapkan tenaga perpustakaan sekolah pada tanggal 12 Agustus 2018, bahwa

“di perpustakaan kita ada koleksi untuk para siswa difabel, karena mereka punya hak yang sama dengan siswa yang lain mbak".

Senada dengan hal tersebut, siswa relawan pustakawan muda juga menyatakan bahwa terdapat koleksi untuk siswa difabel walau jumlahnya masih terbatas.

Perpustakaan bekerja sama dengan pihak sekolah memenuhi kebutuhan siswa difabel ketika akan berkunjung dengan membangun sarana penunjang. Sarana tersebut misalnya tangga landai untuk akses kursi roda. Tidak hanya untuk siswa difabel yang ada di SMAN 2 Bantul tetapi juga untuk siswa difabel dari luar sekolah, seperti siswa sekolah luar biasa (SLB). Hasil wawancara dengan kepala perpustakaan pada tanggal 15 Agustus 2018 menunjukkan bahwa selain melayani siswa difabel, perpustakaan juga menjalin kerja sama dengan sekolah luar biasa di sekitar sekolah.

Hal ini diperkuat dengan hasil wawancara dengan kepala sekolah, bahwa

"kami berinisiatif mengambil kebijakan untuk kerja sama dengan SLB untuk berbagi informasi para siswa difabel di sekolah tersebut".

Berdasarkan hasil observasi di ruang perpustakaan pada saat kegiatan story telling, siswa difabel dari sekolah luar biasa tersebut kelihatan merasa puas dan senang dengan layanan yang diberikan perpustakaan Prapanca. Fasilitas dan kegiatannya dinilai sudah tepat 
dan mendukung program literasi informasi sekolah. Selain itu, siswa difabel merasa terb antu dengan kegiatan tersebut, dan merasa tidak bosan untuk berkunjung ke Perpustakaan Prapanca SMA N 2 Bantul.

\subsubsection{Layanan perpustakaan untuk narapidana di rumah tahanan}

Perpustakaan Prapanca SMAN 2 Bantul juga melayani koleksi di rumah tahanan (Rutan) Pajangan Bantul sebagai bentuk kepedulian sekolah terhadap kebutuhan informasi bagi narapidana di lembaga pemasyarakatan tersebut. Hal ini dilakukan sekolah dengan asumsi bahwa kebanyakan penghuni lembaga pemasyarakatan adalah orang-orang yang haus akan informasi yang semakin luas dan mengalami peningkatan yang cepat.

Berdasarkan hasil wawancara, kepala perpustakaan pada tanggal 20 Agustus 2018 menyatakan bahwa:

"perpustakaan ini juga melayani untuk rutan Pajangan mbak..sudah berlangsung hampir satu tahun. Kepala sekolah waktu itu yang punya gagasan untuk menjalin kerjasama dengan pihak lembaga pemasyarakatan dalam bentuk pemberian lay anan koleksi bahan pustaka kepada narapidana”.

Hasil wawancara dengan tenaga perpustakaan pada tanggal 21 Agustus 2018 juga menghasilkan pandangan yang sama. Ia mengatakan:

"agar dapat memenuhi kebutuhan informasi semaksimal mungkin kepada masyarakat, perpustakaan mengadakan kerja sama dengan rutan Pajangan mbak...dan yang melaksanakan siswa-siswa yang tergabung dalam relawan pustakawan muda. Kita hanya menyiapkan buku-bukunya saja yang untuk ditukar”.

Pemberian layanan bertujuan agar narapidana mendapatkan tambahan wawasan dan pengetahuan serta keterampilan yang dapat diterapkan di kehidupan masyarakat. Di samping itu, kerja sama ini diharapkan dapat mengisi waktu luang dan kejenuhan para narapidana. Oleh karena itu, bentuk layanan perpustakaan SMAN 2 Bantul ke Rutan Pajangan adalah peminjaman koleksi bahan pustaka. Hal ini diungkapkan oleh kepala perpustakaan pada wawancara tanggal 20 Agustus 2018 bahwa.

"kami memberi layanan ke rutan Pajangan dengan tujuan untuk mengusir kejenuhan dan menambah wawasan berupa ilmu pengetahuan dan keterampilan yang berguna saat bebas dan kembali ke masyarakat".

Senada dengan pernyataan tersebut, hasil wawancara dengan tenaga perpustakaan pada tanggal 21 Agustus 2018 mengungkapkan bahwa:

"benar mbak...kami ingin membantu narapidana rutan Pajangan agar melek literasi, dan mengusir kejenuhan dengan rutinitas harian mereka". 
Pernyataan kedua narasumber tersebut diperkuat dengan hasil analisis dokumen tentang daftar inventaris buku. Hasilnya menunjukkan bahwa buku koleksi tersebut sebagian besar berisi cerita fiksi, pengetahuan umum, dan berbagai keterampilan terapan. Hasil observasi di rutan Pajangan menunjukkan siswa relawan pustakawan muda mengganti koleksi sehingga narapidana antusias untuk mengisi waktu luang mereka dengan membaca buku.

\subsubsection{Layanan perpustakaan untuk penghuni di panti jompo}

Program pengembangan layanan perpustakaan yang ketiga adalah layanan perpustakaan yang dilakukan di panti jompo Kasihan Bantul. Aktivitas para manula ini sudah sangat terbatas sehingga seringkali merasa jenuh dengan rutinitasnya. Meskipun begitu, masih ban yak pula yang gemar membaca buku untuk sekedar mengisi waktu luang maupun menambah wawasan. Berdasarkan kondisi tersebut, perpustakaan Prapanca SMAN 2 Bantul memberikan layanan bahan pustaka untuk panti jompo.

Berdasarkan hasil wawancara tanggal 1 September 2018, kepala sekolah mengungkapkan bahwa:

"sama halnya di lembaga pemasyarakatan, perpustakaan ini juga peduli dengan orang tua yang sudah terbatas aktifitas, sehingga pihak sekolah mengambil kebijakan untuk kerja sama dalam hal layanan koleksi bahan pustaka ke panti jompo Kasihan".

Berbeda dengan pendapat kepala sekolah pada hasil wawancara tanggal 2 September 2018, salah seorang partisipan mengungkapkan bahwa

"program pengembangan layanan perpustakaan di panti jompo ini sangat menarik dan merupakan ide kreatif dari kepala perpustakaan. Layanan perpustakaan di panti jompo merupakan bentuk kepedulian sekolah terhadap orang tua untuk mengisi waktu luang dengan kegiatan yang bermanfaat yaitu dengan membaca buku".

Kedua pendapat tersebut dimaknai bahwa program pengembangan layanan perpustakaan di panti jompo merupakan kerja sama antara kepala perpustakaan dan kepala sekolah. Artinya, ide dasar program pengembangan layanan perpustakaan datang dari kepala perpustakaan yang mendapat dukungan sepenuhnya dari kepala sekolah sebagai wujud pengimplementasian literasi bagi masyarakat. Tujuan pelayanan koleksi ke panti jompo ini tidak jauh berbeda dengan di rutan Pajangan, yaitu untuk membantu menghilangkan kejenuhan terhadap kegiatan rutinitas hariannya dan mengisi waktu luan gnya. Koleksi yang disediakan perpustakaan SMAN 2 Bantul lebih banyak berupa koleksi fiksi atau bacaan ringan saja. Hal ini diperkuat melalui hasil observasi di ruang perpustakaan ditemukan tenaga 
perpustakaan yang sedang menginventaris buku-buku fiksi, majalah, surat kabar dan buku pengetahuan sederhana. Hasil analisis dokumen tentang daftar inventaris buku juga memperlihatkan data-data buku yang dipinjamkan ke panti jompo Kasihan.

\subsection{Proses bentuk layanan perpustakaan sekolah}

Implementasi bentuk program layanan perpustakaan membutuhkan proses pengorganisasian, pengarahan, dan monitoring (evaluasi) yang berkesinambungan. Kegiatan pengorganis asian dalam hal pengembangan layanan perpustakaan tertera dalam struktur organisasi mikro perpustakaan. Hasil analisis dokumen tentang struktur organisasi perpustakaan secara mik ro menunjukkan bahwa program pengembangan layanan perpustakaan merupakan salah satu program kerja kepala perpustakaan. Program itu diawasi langsung oleh kepala sekolah sebagai penanggungjawab penyelenggaraan perpustakaan sekolah.

Pada pelaksanaan kegiatan, kepala perpustakaan bekerja sama dengan tenaga perpustakaan dan siswa yang tergabung dalam relawan pustakawan muda. Tim yang direkrut oleh kepala perpustakaan diserahi tugas dan tanggungjawab masing-masing. Informasi tersebut peneliti dapatkan dari hasil wawancara dengan kepala perpustakaan yang menjelaskan bahwa,

"dalam pelaksanaanya saya dibantu oleh tenaga perpustakaan dan siswa yang tergabung dalam tim relawan pustakawan muda, yang masing-masing sudah tak serahi tugas dan tanggungjawabnya”.

Kegiatan pengarahan dilakukan kepala sekolah dan dilakukan oleh kepala perpustakaan agar pelaksanaan tugas dapat berjalan lancar. Hal ini dipaparkan oleh tenaga perpustakaan sebagai hasil wawancara pada tanggal 4 September 2018 bahwa,

"kami selalu di briefing dulu setiap mau melaksanakan tugas, sehingga kami tidak kesulitan dalam pelaksanaan tugas". Demikian juga yang diungkapkan oleh siswa relawan pustakawan muda dalam wawancara tanggal 4 September 2018 bahwa, "kami dikasih tau dulu apa yang harus kami lakukan di lapangan ...dalam hal ini dilakukan oleh bapak kepala perpustakaan sekolah".

Kegiatan monitoring dan evaluasi dilakukan oleh kepala perpustakaan secara berkala . Kegiatan ini dilakukan kepala perpustakaan dengan melakukan kegiatan kunjungan langsung ke lapangan dan mengadakan wawancara informal tentang koleksi yang dibutuhkan dan kepuasan para pengguna koleksi bahan pustaka.

\subsubsection{Proses layanan perpustakaan untuk siswa difabel}


Perpustakaan Prapanca SMAN 2 Bantul memberikan layanan perpustakaan khusus seperti kegiatan storytelling (membacakan cerita) yang dilakukan oleh pustakawan relawan muda bagi siswa difabel. Tahap yang dilakukan terdiri atas beberapa kegiatan. Pada tahap pertama, dilakukan kerja sama pihak perpustakaan dengan SLB yang ada di sekitar sekolah. Tahap kedua, setelah terjalin kesepakatan kerja sama, pihak perpustakaan mengundang siswa-sis wa difabel untuk berkunjung ke perpustakaan sekolah dalam hari dan jam yang sudah ditentukan. Tahap ketiga, siswa relawan muda mempersiapkan bahan atau materi yang berasal dari bukubuku yang ada di perpustakaan.

Selanjutnya, pada hari pelaksanaan kegiatan, siswa relawan pustakawan muda saling bekerja sama dan menjalankan kegiatan story telling. Kegiatan story telling biasanya dilakukan di ruang pameran atau di ruang audio visual, karena ruangan ini luas sehingga mampu menampung banyak siswa dan nyaman untuk digunakan.

Hal ini diperkuat dengan hasil wawancara dengan FAZ (siswa yang tergabung relawan pustakawan muda) pada tanggal 4 September 2018, yang mengungkapkan bahwa.

"story telling biasa kami lakukan di ruang pameran atau ruang audio visual karena luas dan nyaman, di samping itu fasilitas pendukungnya tersedia".

Hal senada juga dipaparkan S (siswa relawan pustakawan muda) dalam wawan car a tanggal yang sama yaitu 4 September 2018, bahwa.

"kegiatan itu dilakukan di ruang pameran atau ruang audio visual, selain luas ruangan ini penataanya fasilitasnya rapi sehingga nyaman untuk digunakan”.

Berdasarkan hasil observasi di ruang tersebut menunjukkan bahwa memang ruangannya luas dan fasilitas pendukungnya ditata dengan rapi sehingga nyaman apabila digunakan. Terkait layanan story telling ini, dalam hasil observasi pada saat kegiatan berlangsung ditemukan bahwa siswa difabel terlihat puas dan senang dengan layanan ini. Hal ini disebabkan karena layanan yang diberikan perpustakaan tidak monoton dan selalu berganti tema yang diceritakan. Para relawan pustakawan muda dengan penuh perhatian dan kesabaran, memiliki rasa tanggung jawab yang tinggi, serta memiliki kemampuan dalam menanggapi dan mendampingi siswa difabel.

\subsubsection{Proses layanan di rumah tahanan}

Proses pemberian layanan ke rumah tahanan Pajangan dilakukan Perpustakaan SMA N 2 Bantul dengan bekerjasama dengan relawan pustakawan muda. Layanan perpustakaan dalam bentuk meminjamkan koleksi bagi para narapidana dengan membawa koleksi perpustakaan 
yang sesuai dengan kebutuhan narapidana. Koleksi tersebut dibawa oleh relawan pustakawan muda dan diganti tiap dua bulan sekali.

Informasi ini didapatkan pada hasil wawancara dengan kepala perpustakaan pada tanggal 6 September 2018, yang menjelaskan bahwa,

"memang buku koleksi perpustakaan yang dibawa ke rutan Pajangan oleh relawan pustakawan muda, dan diganti dua bulan sekali”.

Demikian juga pernyataan tenaga perpustakaan berdasarkan hasil wawancara tan ggal 8 September 2018, bahwa

"iya mbak, kami meminjamkan koleksi untuk dibaca di rutan Pajangan, hal ini dilakukan oleh relawan pustakawan muda secara bergantian, dua bulan sekali buku diganti”.

Koleksi merupakan buku pilihan dari tenaga perpustakaan dan sebagian merupakan pesanan dari para narapidana.

Pengolahan buku bahan pustaka berada di perpustakaan Prapanca SMA N 2 Bantul, sehingga lembaga pemasyarakatan hanya tinggalkan memanfaatkan saja. Kegiatan pengembangan layanan di lembaga pemasyarakatan ini dilakukan secara rutin dan berkesinambungan. Setiap dua bulan sekali diadakan kegiatan evaluasi agar dapat memberikan pelayanan yang terbaik. Tingkat kepuasan para narapidana selalu dimonitor dan hasilnya digunakan sebagai pijakan dalam program pengembangan layanan selanjutnya. Hal ini sesuai dengan pernyataan kepala perpustakaan bahwa kegiatan ini diawasi dan dievaluasi pelaksanaannya setiap dua bulan sekali untuk mengetahui kendala dan kebutuhan narapidana akan koleksi yang dibutuhkan. Berdasarkan hasil wawancara dengan relawan pustakawan muda mengatakan bahwa para narapidana merasa sangat senang dan terbantu dengan layanan perpustakaan Prapanca SMA N 2 Bantul ini. Para narapidana merasa tidak jenuh dengan rutinitas kegiatan yang ada di lembaga pemasyarakatan dengan adanya koleksi bahan pustaka yang bisa dibacanya.

\subsubsection{Proses layanan di panti jompo}

Layanan perpustakaan di panti jompo Kasihan juga dalam bentuk meminjamkan koleksi bahan pustaka. Koleksi dikelola di perpustakaan Prapanca sehingga pihak panti jompo hanya tinggal memanfaatkan saja. Hal ini juga berdasarkan hasil wawancara dengan kepala perpustakaan tanggal 6 September 2018 bahwa,

"iya mbak...sama dengan di rutan pajangan, karena siswa relawan pustakawan m u da sekalian jalan, dan kadang mereka bagi tugas, ada yang ke rutan Pajangan, ada yang ke panti Jompo Kasihan. Saya serahkan kepada mereka untuk mengaturnya”. 
Demikian pula yang dikatakan tenaga perpustakaan pada tanggal 6 September 2018 bahwa,

"prosesnya sama dengan di rutan Pajangan, dan pelaksanaannya fleksibel dis erahkan ke siswa penjadwalannya".

Dalam waktu tertentu, dilakukan evaluasi untuk menilai keberlanjutan program tersebut. Menurut relawan pustakawan muda, para lansia merasa terhibur dan dapat menambah aktivitas sehingga dapat mengurangi kejenuhan.

Perpustakaan Prapanca menyediakan buku koleksi bahan pustaka yang sesuai dengan kebutuhan penghuni panti jompo. Koleksi yang ditukarkan adalah koleksi yang dipilih oleh petugas perpustakaan dan hasil pesanan warga di panti jompo. Lebih lanjut dikatakan bahwa pelayanan pengguna di panti jompo memerlukan kesabaran dan dilakukan dengan penuh perhatian karena karakteristik penggunanya sudah tua. Tidak jarang pula ketika waktu luang, petugas panti jompo harus melakukan kegiatan menceritakan kembali isi buku kepada penggunanya. Hal ini dilakukan karena tidak semua pengguna mampu membaca dengan baik buku tersebut karena faktor usia.

\section{PEMBAHASAN}

\subsection{Layanan perpustakaan bagi siswa difabel}

Pada dasarnya, semua upaya kegiatan layanan yang diberikan perpustakaan sekolah adalah bertujuan untuk memuaskan pengguna termasuk siswa yang memiliki kebutuhan khusus (difabel). Oleh karena itu, perpustakaan sekolah perlu didukung fasilitas yang memadai untuk anak difabel. Hal ini merupakan suatu bentuk kepedulian perpustakaan sekolah terhadap anak difabel dengan menyediakan aksesibilitas baik fisik maupun non fisik. Di samping itu, perlu adanya kebijakan yang mendukung persamaan hak bagi anak difabel dalam mengakses informasi sehingga perpustakaan diharuskan memberikan layanan yang prima terhadap anakanak difabel. Pengembangan program layanan di Perpustakaan Prapanca SMAN 2 Bantul ini sudah menerapkan prinsip-prinsip pelayanan prima. Adapun prinsip-prinsip pelayanan prima tersebut antara lain:

1. Attentiveness, penuh perhatian. Dalam hubungannya dengan kehidupan sosial, sifat penuh perhatian ini diperlukan sebagai bentuk kepedulian terhadap orang lain, teru ta ma ketika seseorang membutuhkan bantuan.

2. Responsibility, tanggung jawab. Suatu bentuk aktivitas sosial dalam rangka menerima konsekuensi dengan apa yang telah dilakukan. 
3. Competence, kemampuan. Merupakan keahlian yang dimiliki oleh setiap individu dalam rangka mempertahankan hidup.

4. Responsiveness, kemampuan menanggapi. Merupakan bentuk kemampuan bereaksi untuk menanggapi sesuatu hal yang muncul dan menggugah keinginan untuk mere spon keberadaannya (Suwarno, 2014: 97).

Namun karena keterbatasan tenaga perpustakaan dan siswa relawan pustakawan muda dalam berkomunikasi dengan anak-anak difabel, proses kegiatan dibatasi hanya pada kegiatan story telling bagi siswa difabel di sekitar sekolah. Selain itu, perpustakaan sekolah juga telah berusaha melengkapi fasilitas agar akses ke perpustakaan bagi anak difabel menjadi lebih mudah. Program pengembangan layanan perpustakaan ini cukup efektif untuk memberikan hak yang sama atas informasi yang selalu berkembang.

\subsection{Layanan perpustakaan di rumah tahanan}

Layanan perpustakaan merupakan penyediaan bahan pustaka secara gratis kepada masyarakat penggunanya secara tepat dan akurat sesuai dengan kebutuhan informasi penggunanya. Pelayanan perpustakaan sesuai dengan kebutuhan pengguna merupakan tolok ukur keberhasilan perpustakaan. Kegiatan pengembangan layanan perpustakaan ini juga merupakan bentuk promosi perpustakaan kepada masyarakat umum tentang keberadaaan perpustakaan sekolah.

Perpustakaan sekolah perlu untuk mengembalikan fungsi dan tujuan utama perpustakaan sekolah yaitu sebagai salah satu sumber informasi dan menjadi jendela dunia bagi masyarakat penggunanya. Hal ini senada dengan pendapat Hartono (2016; 217), perpustakaan sekolah perlu melakukan promosi, artinya petugas perpustakaan yang melakukan pelayanan peminjaman secara langsung kepada pengguna, seperti kepad a pasien rumah sakit, rumah jompo, atau rumah tempat tinggal di mana ada salah seorang anggota keluarga yang tidak dapat datang ke perpustakaan. Selain itu, perpustakaan Prapanca SMAN 2 Bantul juga ini telah menerapkan model pendidikan berbasis masyarakat layanan langsung (direct service model), yaitu model yang menyediakan kegiatan layanan secara langsung terhadap kebutuhan masyarakat.

Dengan model ini, sekolah mengirimkan siswa ke dalam kehidupan masyarakat untuk memberikan pelayanan (Fuad, 2014: 163). Kegiatan layanan langsung dilakukan perpustakaan SMAN 2 Bantul dengan mengirimkan siswa untuk melayani masyarakat terutama para narapidana di rumah tahanan Pajangan Bantul. Kegiatan ini bertujuan selain menyelenggarakan literasi informasi bagi masyarakat, juga merupakan upaya untuk 
mendidik, mengajar, dan melatih siswa untuk memiliki rasa tanggungjawab atas tindakan atau kegiatan masyarakat, serta memberi pemahaman kepada siswa bahwa siswa dapat melakukan hal yang berbeda dari biasanya.

\subsection{Layanan perpustakaan di panti jompo Kasihan}

Pelayanan berbasis institusi atau pelayanan yang diselenggarakan dalam panti jompo merupakan salah satu alternatif model pelayanan bagi lansia, selain pelayanan yang berbas is keluarga dan komunitas. Panti jompo merupakan tempat yang perlu mendapat perhatian lebih dengan mempertimbangkan kondisi penghuni lanjut usia (lansia) yang mulai mengalami penurunan kondisi baik fisik maupun psikologis dengan kegiatan layanan yang prima. Tujuannya yaitu menjadikan lansia yang memiliki kebutuhan khusus baik sarana maupun prasarana untuk menunjang kemandirian dalam beraktivitas. Selain itu, secara psikologis perlu diupayakan meningkatkan pandangan masyarakat tentang panti jompo yang u mu mny a masih bercitra negatif. Selain dikonotasikan dengan kekumuhan, panti jompo juga disebut sebagai tempat pembuangan lansia.

Pelayanan pengguna di panti jompo memerlukan kesabaran dan perhatian karena karakteristik penggunanya sudah tua. Petugas panti jompo tidak jarang harus melakukan kegiatan menceritakan kembali isi buku kepada penggunanya di waktu luang. Hal ini dilakukan karena tidak semua lansia mampu membaca dengan baik buku. Oleh karena itu, pada proses interaksi belajar dalam pendidikan orang dewasa, kegiatan dan pe ranan fasiltator tidak hanya memindahkan pengetahuan dan keterampilan kepada lansia. Fungsi dan peranan fasilitator dalam hal ini adalah siswa relawan pustakawan muda, yaitu mendorong dan melibatkan seluruh penghuni dalam proses interaksi secara mandiri, yaitu proses belajar untuk memahami permasalahan nyata yang dihadapi, memahami kebutuhan belajarnya sendiri, dan mendiagnosis kembali kebutuhan belajarnya dari waktu ke waktu (Fuad, 2014: 176).

Mitchell (2006) menyebutkan syarat desain layanan yang lebih memudahkan bagi lansia. Syarat tersebut yaitu keakraban (familiarity), mudah dibaca (legibility), jelas (distinctiveness), mudah dicapai (accessibility), nyaman (comfort) dan aman (security). Beberapa persyaratan tersebut telah dipertimbangkan oleh perpustakaan Prapanca SMAN 2 Bantul dalam memberikan layanan penghuni panti jompo di Kasihan Bantul. Upaya untuk meningkatkan kualitas hidup para lansia di panti jompo memerlukan motivasi petugas layanan untuk mengembangkan dukungan, interaktif, dan hubungan peduli kolaboratif dengan penghuni (Lee at al., 2009: 123). Uraian ini menunjukkan bahwa peningkatkan 
kualitas hidup para lansia sangat penting dilakukan. Salah satu caranya yaitu dengan memberikan layanan perpustakaan yang prima, yang dilakukan oleh para siswa relawan pustakawan muda yang selalu memberikan dukungan, interaksi yang intensif dengan para lansia, menjalin kerja sama dengan lansia untuk mengetahui kebutuhannya dan kolaborasi dengan pihak panti jompo untuk keberlanjutan program layanan perpustakaan.

\section{SIMPULAN}

Program pengembangan layanan di perpustakaan Prapanca SMAN 2 Bantul merupakan salah satu pengembangan perpustakaan dengan tujuan untuk meningkatkan kualitas layanan perpustakaan dan menjaga keberadaan fungsi dan peranan perpustakaan sebagai sumber belajar. Program pengembangan layanan di perpustakaan Pranpanca meliputi kegiatan layanan untuk siswa difabel, narapidana di rumah tahanan, dan layanan perpustakaan di panti jompo. Proses layanan perpustakaan dilakukan oleh siswa relawan pustakawan muda, dengan kegiatan story telling untuk melayani siswa difabel, peminjaman buku ke rumah tahanan Pajangan dan panti jompo Kasihan dengan mengganti buku tiap dua bulan sekali. Kegiatan monitoring dan evaluasi pada layanan dilakukan secara berkala untuk mengetahui hambatan dan keberlanjutan program. Pelayanan perpustakaan yang prima di SMAN 2 Bantul dapat dijadikan teladan bagi manajemen perpustakaan sekolah lainya dalam berbagai jenjang pendidikan dan dapat dijadikan acuan dalam pengembangan program perpustakaan sekolah yang selanjutnya.

\section{DAFTAR PUSTAKA}

Fuad, N. (2014). Manajemen pendidikan berbasis masyarakat. Jakarta: Raja Grafindo. Grates, F. (2013). School library impact studies: a review of findings and guide to sources. Gretes Research Servises. Retrieved from https://www.baltimorelibraryproject,org/ Hartono. (2016). Manajemen perpustakaan sekolah; menuju perpustakaan modern dan profesional. Yogyakarta: Ar-Ruzz Media.

Hartono. (2017). Strategi pengembangan perpustakaan digital dalam membangun aksesbilitas informasi: sebuah kajian teoritis pada perpustakaan perguruan tinggi islam di Indonesia. Jurnal Perpustakaan, Vol. 8, No. 1, 75-91. ISSN 1979 - 9527. Retrieved form https://journal.uii.ac.id/unilib/article/view/11487/8666

Inderiyeni. (2017). Evaluasi sistem layanan perpustakaan di SMK Kehutanan Negeri Pekanbaru. Jurnal Pustaka Budaya, Vol. 4, No. 1, 17-32.

Lince, E.N. (2012, October 08). 76.000 sekolah belum memiliki perpustakaan. KOMPAS. Retrieved from https://edukasi.kompas.com/read/2012/10/08/11070712/76.000.Sekolah.Belum.Memil $\underline{\text { iki.Perpustakaan }}$ 
Lee DTF, Yuu DSF, \& Kwong ANL. (2009). Quality of life of older people in residential care home: a literature review. Jurnal of nursing and healthcare of Chronic Illness. 1(2), 116-125. Hongkong: Backwell Publishing Ltd. doi: 10.1111 / j.17529824.2009.01018.x.

Mansyur, M. (2015). Manajemen perpustakaan sekolah. Jurnal Pustakaloka, Vol. 7 No. 1, 43-54. DOI: https://doi.org/10.21154/pustakaloka.v7i1.184

Mitchell, E. B. (2006). Inclusive urban design: streets for life. UK: Elsevier.

Peraturan Menteri Pendidikan Nasional (Permendiknas) No. 20 Tahun 2007 tentang Standar Sarana dan Prasarana untuk SD/MI, SMP/MTS, SMA/MA

Peraturan Pemerintah No. 32 Tahun 2013 tentang perubahan atas PP No. 19 tahun 2005 tentang Standar Nasional Pendidikan

Peraturan Pemerintah No. 19 Tahun 2005 tentang Standar Nasional Pendidikan

Prastowo, A. (2012). Manajemen perpustakaan sekolah profesional. Yogyakarta: Diva Press.

Qalyubi, S, dkk. (2007). Dasar-dasar ilmu perpustakaan dan informasi. Yogyakarta: Jurusan Ilmu Perpustakaan dan Informasi Universitas Fakultas Adap UIN Sunan Kalijaga Yogyakarta

Suwarno, W. (2014). Ilmu perpustakaan dan kode etik pustakawan. Yogyakarta: Ar-Ruzz Media.

Undang-Undang Republik Indonesia Nomor 43 Tahun 2007 tentang Perpustakaan. 